\title{
Biological differences between in vitro produced bovine embryos and parthenotes
}

\author{
Enrique Gómez, Alfonso Gutiérrez-Adán ${ }^{1}$, Carmen Díez, Pablo Bermejo-Alvarez , \\ Marta Muñoz, Aida Rodriguez, Jesús Otero², María Alvarez-Viejo², David Martín, \\ Susana Carrocera and José Néstor Caamaño
}

Genética y Reproducción Animal, SERIDA, Camino de los Claveles 604, 33203 Gijón, Asturias, Spain, ${ }^{1}$ INIA, Departamento de Reproducción Animal y Conservación de Recursos Zoogenéticos, Cra de La Coruña Km 5600, 28040, Madrid, Spain and ${ }^{2}$ Hospital Universitario Central de Asturias, Oviedo, 33006 Asturias, Spain

Correspondence should be addressed to E Gómez; Email: egomez@serida.org

\begin{abstract}
Parthenotes may represent an alternate ethical source of stem cells, once biological differences between parthenotes and embryos can be understood. In this study, we analyzed development, trophectoderm (TE) differentiation, apoptosis/necrosis, and ploidy in parthenotes and in vitro produced bovine embryos. Subsequently, using real-time PCR, we analyzed the expression of genes expected to underlie the observed differences at the blastocyst stage. In vitro matured oocytes were either fertilized or activated with ionomycin + 6-DMAP and cultured in simple medium. Parthenotes showed enhanced blastocyst development and diploidy and reduced TE cell counts. Apoptotic and necrotic indexes did not vary, but parthenotes evidenced a higher relative proportion of apoptotic cells between inner cell mass and TE. The pluripotence-related POU5F1 and the methylation DNMT3A genes were downregulated in parthenotes. Among pregnancy recognition genes, TP-1 was upregulated in parthenotes, while PGRMC1 and PLAC8 did not change. Expression of $p 66^{\text {shc }}$ and $B A X / B C L 2$ ratio were higher, and $p 53$ lower, in parthenotes. Among metabolism genes, SLC2A1 was downregulated, while AKR1B1, PTGS2, H6PD, and $T X N$ were upregulated in parthenotes, and SLC2A5 did not differ. Among genes involved in compaction/blastulation, GJA1 was downregulated in parthenotes, but no differences were detected within ATP1A1 and CDH1. Within parthenotes, the expression levels of $S L C 2 A 1, T P-1$, and $H 6 P D$, and possibly $A K R 1 B 1$, resemble patterns described in female embryos. The pro-apoptotic profile is more pronounced in parthenotes than in embryos, which may differ in their way to channel apoptotic stimuli, through $\mathbf{p 6 6}^{\text {shc }}$ and $\mathbf{p 5 3}$ respectively, and in their mechanisms to control pluripotency and de novo methylation.

Reproduction (2009) 137 285-295
\end{abstract}

\section{Introduction}

Parthenogenetic activation of oocytes allows study of the roles of paternal and maternal genomes in early mammalian development. Parthenogenesis is a process by which the oocyte develops without the male gamete. This form of reproduction is not spontaneous in mammals, although it is an extended reproductive procedure in fish, amphibians, and snake, among other organisms. Parthenotes may represent an alternative ethical source of stem cells, once biological differences between parthenotes and embryos can be understood (Brevini \& Gandolfi 2008). Parthenogenetic activation is a major step in nuclear transfer, which may facilitate or improve the genomic reprogramming of a reconstructed embryo and increase its chance of reproductive success (Kim et al. 1996). Matured mammalian oocytes remain arrested in metaphase II stage, a blockage in development that has been suggested to occur as an evolutionary safety mechanism to prevent parthenogenesis inside the female (Cibelli et al. 2006). The oocyte is released from its blocked stage when the fertilizing spermatozoon triggers multiple and rhythmic oscillations of intracellular free calcium (Yang et al. 1994). A variety of chemicals can mimic the intracellular calcium patterns and activate the oocyte without sperm (Cibelli et al. 2006) to yield parthenogenetic embryos. The combination of activators with either protein synthesis inhibitors or kinase inhibitors seems to be more efficient than single activation procedures (Jellerette et al. 2004), which has been recently confirmed in the bovine species (Wang et al. 2008).

Once transferred to surrogate mothers, parthenotes are unable to develop to term, although they can go through gastrulation and early stages of organogenesis. Essential alterations in parthenotes affect not only the trophoblast (something precociously evident at the blastocyst stage), but also parts of the embryo proper, such as muscle, liver, and pancreas (Fundele et al. 1989, 1990). In the cow, the 
Table 1 Cumulative embryo development of in vitro matured bovine oocytes fertilized or parthenogenetically activated with ionomycin + 6-DMAP.

\begin{tabular}{|c|c|c|c|c|c|c|c|c|}
\hline \multirow[b]{2}{*}{ Group } & \multirow[b]{2}{*}{$N$} & \multirow[b]{2}{*}{$\mathbf{R}$} & \multicolumn{3}{|c|}{ Percentage of Day 3 embryos } & \multicolumn{3}{|c|}{ Percentage of Day 8 blastocysts } \\
\hline & & & Cleaved & 5-8 Cells & 8-16 Cells & Total & Expanded & Hatched \\
\hline Parthenotes & 899 & 17 & $81.4 \pm 1.6$ & $38.1 \pm 2.3^{\mathrm{x}}$ & $7.3 \pm 1.7^{x}$ & $42.4 \pm 3.0^{\mathrm{x}}$ & $29.5 \pm 2.7^{x}$ & $3.0 \pm 1.1$ \\
\hline Embryos & 1089 & 17 & $85.1 \pm 1.5$ & $68.2 \pm 2.3^{y}$ & $24.2 \pm 1.7^{y}$ & $31.2 \pm 2.9^{y}$ & $20.4 \pm 2.7^{y}$ & $3.1 \pm 1.0$ \\
\hline
\end{tabular}

Data are LSM \pm S.E.M. as proportions of cultured oocytes. Different superscripts express significant differences $(x, y: P<0.01)$. $N$, oocytes in culture; $\mathrm{R}$, replicates.

maximum development in uterus reached by a parthenogenetic embryo has been reported to be of 48 days (Fukui et al. 1992). The arrest in development of parthenotes is thought to be due to alterations in their genomic imprinting, which in turn seems to be an evolutive result of conflicts between the parental genomes during growth (Brevini \& Gandolfi 2008). Maternal and paternal genes are reciprocally imprinted, such that both genomes are needed for correct growth, being complementary but not equivalent (Smith 2001). Therefore, monoparental duplication of gene expression would lead to embryonic lethality. A recent review identified more than 50 imprinted genes expressed in humans (Brevini \& Gandolfi 2008); these and other nonimprinted genes could be therefore altered at early embryonic stages. The endpoint normally used in parthenogenetic experiments in vitro is the development up to the blastocyst stage (Cibelli et al. 2006). Studies on differential cell counts between IVF embryos and parthenotes are scarce (de la Fuente \& King 1998, Van de Velde et al. 1999, Neuber et al. 2002), and the information on apoptosis is usually limited to the DNA damage phenotype (Neuber et al. 2002, Hao et al. 2004, Wang et al. 2008) without a focus to distinguish histological traits of necrotic and apoptotic nuclei and without a detailed gene expression study as a way to explore underlying mechanisms. An expression analysis covering genes representative of essential events in development could help to understand alterations in genomic imprinting, cell differentiation, and apoptosis showed by parthenotes.

In the present work, we analyze differences between the parthenotes and IVF embryos in blastocyst development, allocation of cells to the trophectoderm (TE) and the inner cell mass (ICM), and apoptosis/necrosis. Subsequently, we quantify the levels of mRNA transcription within a panel of genes related to functionality of the epiblast, TE, and pregnancy recognition, metabolism, apoptosis and growth arrest, and morula compaction and blastocyst formation.

\section{Results \\ Development, differential cell counts, and apoptosis/ necrosis analysis}

In vitro development is shown in Table 1. Parthenotes and embryos exhibited a markedly different developmental pattern. Embryos showed significantly increased development rates at cleavage stages and at the embryonic genome major activation stage (i.e. 8- to 16-cell stage), while parthenotes showed enhanced blastocyst and expansion rates. No differences were noted at hatching. Parthenotes showed a significant reduction in TE cell counts (Table 2), which in turn accounted for a reduction in total cells. However, ICM cells and the proportions of ICM/total cells did not differ between parthenotes and embryos. Apoptotic and necrotic indexes (NI) did not vary (Table 3), although parthenotes evidenced a higher proportion of apoptotic cells in their ICM over that in TE cells.

\section{Gene transcription analysis}

Four pools of 15 embryos per treatment were analyzed in duplicated PCRs.

Figure 1 shows the genes involved in metabolism and compaction/blastocyst formation. Among metabolism related genes, H6PD, AKR1B1, PTGS2 (COX2), and $T X N$ genes were upregulated in parthenotes, while $S L C 2 A 1$ was upregulated in embryos, and SLC2A5 did not show differences. Within compaction and blastocyst formation genes, GJA1 (connexin-43; CX43) was upregulated in embryos, while $C D H 1$ (E-cadherin) and ATP1A1 did not differ between embryos and

Table 2 Numbers of cells contained in the trophectoderm (TE), inner cell mass (ICM), and percentage of inner cell mass/total cells from bovineexpanded blastocysts derived from oocytes activated with 6-DMAP-ionomycin or fertilized.

\begin{tabular}{|c|c|c|c|c|c|c|c|}
\hline \multirow[b]{2}{*}{ Treatment } & \multirow[b]{2}{*}{$N$} & \multicolumn{2}{|c|}{ ICM } & \multicolumn{2}{|c|}{ TE } & \multirow[b]{2}{*}{ Total } & \multirow[b]{2}{*}{ Percentage of ICM/total } \\
\hline & & No. of cells & Range & No. of cells & Range & & \\
\hline Parthenotes & 24 & $31.4 \pm 3.5$ & $0-60$ & $94.1 \pm 9.9^{x}$ & $52-178$ & $123.9 \pm 11.4^{x}$ & $24.7 \pm 2.2$ \\
\hline Embryos & 20 & $32.5 \pm 3.4$ & $0-57$ & $126.3 \pm 9.5^{y}$ & $60-202$ & $161.3 \pm 10.7^{y}$ & $22.2 \pm 2.1$ \\
\hline
\end{tabular}

Data are LSM \pm S.E.M. (four replicates). $N$, number of embryos counted. $x, y(P<0.01)$. 
Table 3 Apoptotic and necrotic index in the inner cell mass (ICM), trophectoderm (TE), and total cells, dead cell index (DCI: total TUNEL positive cells), plus relative proportions of apoptotic cells between the ICM and TE (ICM/TE, as a percentage) of day 8 parthenogenetic and fertilized bovine blastoycsts.

\begin{tabular}{|c|c|c|c|c|c|c|c|c|c|}
\hline \multirow[b]{2}{*}{ Group } & \multirow[b]{2}{*}{$N$} & \multicolumn{3}{|c|}{ Apoptotic index } & \multirow{2}{*}{$\begin{array}{l}\text { Apoptosis } \\
\text { ICM/TE }\end{array}$} & \multicolumn{3}{|c|}{ Necrotic index } & \multirow[b]{2}{*}{ DCI } \\
\hline & & ICM & TE & Total & & ICM & TE & Total & \\
\hline Parthenotes & 23 & $3.1 \pm 0.8$ & $1.3 \pm 0.4$ & $2.1 \pm 0.3$ & $1.40 \pm 0.2^{\mathrm{a}}$ & $3.5 \pm 1.0$ & $3.1 \pm 0.8$ & $3.2 \pm 0.6$ & $5.3 \pm 0.8$ \\
\hline Embryos & 20 & $2.3 \pm 0.8$ & $2.3 \pm 0.4$ & $2.3 \pm 0.4$ & $0.86 \pm 0.2^{b}$ & $2.3 \pm 0.9$ & $2.7 \pm 0.7$ & $2.4 \pm 0.6$ & $4.7 \pm 0.8$ \\
\hline
\end{tabular}

Data are LSM \pm S.E.M. from four replicates $(\mathrm{a}, \mathrm{b}: P=0.03)$.

parthenotes. Figure 2 shows the genes involved in pluripotency/de novo methylation, apoptosis, and pregnancy recognition. The pluripotency-related gene POU5F1 (Oct3/4) and the de novo methylation

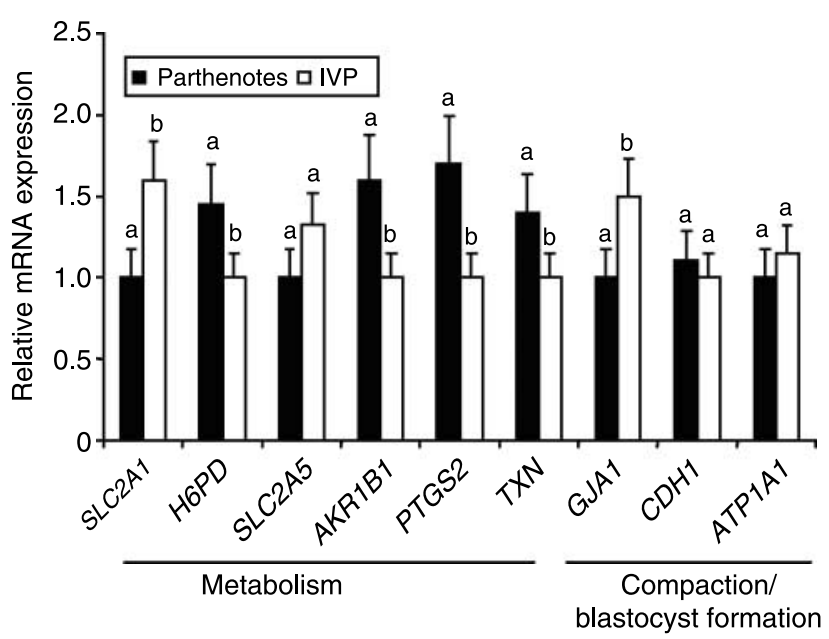

Figure 1 Relative mRNA transcription in bovine in vitro fertilized and parthenogenetic blastocysts of genes involved in metabolism and compaction/blastocyst formation (superscripts express significant differences within a gene; $P<0.05)$.

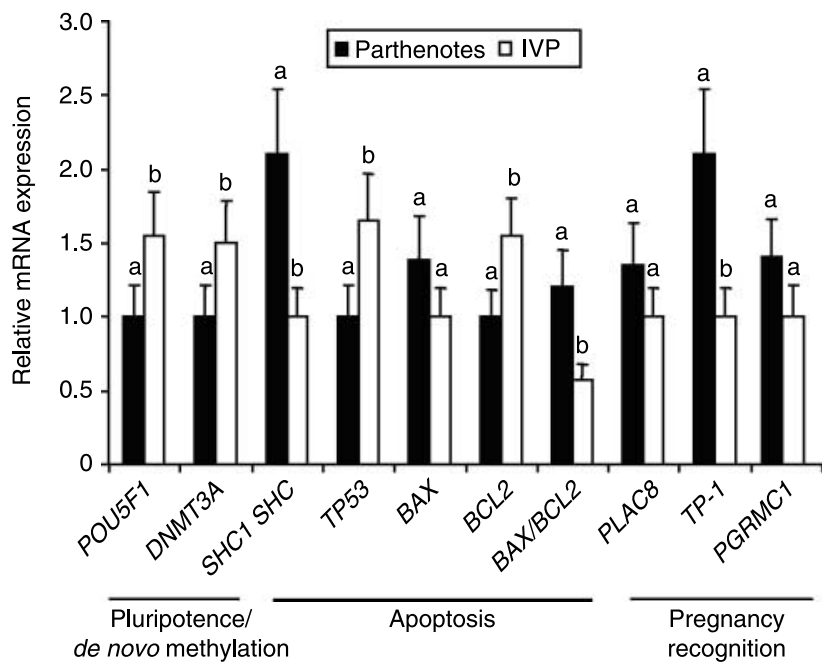

Figure 2 Relative mRNA transcription in bovine in vitro fertilized and parthenogenetic blastocysts of genes involved in pluripotency/de novo methylation, apoptosis, and pregnancy recognition (superscripts express significant differences within a gene; $P<0.05)$.
DNMT3A gene are downregulated in parthenotes. Among the growth arrest and apoptotic genes, the stress sensor SHC1SHC $\left(p 66^{\text {sh }}\right)$ is upregulated in parthenotes; this is contrary to TP53 (p53) that shows downregulation in these blastocysts. The pro-apoptotic gene $B A X$ did not change, while $B C L 2 L 1$ (BCL2) expression decreases in parthenotes. The resulting $B A X / B C L 2 L 1$ ratio was higher in parthenotes, suggesting a pro-apoptotic status. TP-1 doubled its expression level in parthenotes, while PGRMC1 and PLAC8 did not differ.

\section{Ploidy analysis}

Parthenotes showed higher diploid and lower haploid rates than IVF embryos (see Table 4). In fact, no parthenote was found to be haploid, while no IVF embryo was judged as polyploid. Mixoploid rates did not differ.

\section{Discussion}

The present study shows that parthenotes and IVF bovine embryos have different patterns of development. Both groups have similar first cleavage rate, but parthenotes developed at rates lower than IVF embryos during subsequent earlier stages, as seen on day 3 . However, parthenotes proceeded faster once the compacted morula stage was reached (day 6). In agreement with our results, parthenotes were reported to show a first cleavage rate comparable with IVF embryos (Van de Velde et al. 1999). Using time-lapse cinematography, Neuber et al. (2002) showed that the first cleavage occurred earlier in parthenotes than in IVF embryos, although, in agreement with our observations, second and third cleavages showed lower rates in parthenotes than in IVF embryos. DNA synthesis starts earlier in parthenotes than in IVF embryos (De la Fuente \& King 1998). Therefore, the differences reported herein could be due to the use of a specific bull for IVF, as bulls affect

Table 4 Ploidy in bovine parthenogenetic and IVF bovine embryos.

\begin{tabular}{lcclcl}
\hline \multicolumn{1}{c}{ Group } & N & Diploid & Polyploid & Mixoploid & Haploid \\
\hline Parthenote & 29 & $79.3 \pm 8.5^{\mathrm{a}}$ & $6.9 \pm 3.3$ & $13.4 \pm 7.6$ & $0.0^{\mathrm{a}}$ \\
Embryos & 30 & $56.6 \pm 8.4^{\mathrm{b}}$ & 0.0 & $30.0 \pm 7.5$ & $13.8 \pm 4^{\mathrm{b}}$
\end{tabular}

$N$, blastocysts counted. Chromosomal status expressed as LSM \pm S.E.M. Superscripts $(\mathrm{a}, \mathrm{b})$ express significant differences $(P<0.05)$. 
cleavage rates, developmental kinetics, blastocyst yields, and blastocyst quality (reviewed in Vandaele et al. (2006)). The paternal genome is actively demethylated in IVF embryos and it transcribes before the maternal complement does (Gutierrez-Adan et al. 1997, Reik et al. 2003). The slower development in parthenotes at earlier stages may relate to the absence of an active paternal genome. The results of this study indicated that parthenotes contained fewer cells in the TE than IVF embryos, which led to a reduction in total cells. This abnormality has been well described by other authors who studied total cells in bovine parthenotes (Van de Velde et al. 1999, Kubisch et al. 2003, Wang et al. 2008) or, TE and ICM differentially (de la Fuente \& King 1998, Neuber et al. 2002). However, cells in the ICM were reported to be reduced (de la Fuente \& King 1998) or, consistent with our results, unaltered (Neuber et al. 2002). Reductions in cell numbers seem to be a rule in parthenotes of all species (Surani et al. 1984, NewmanSmith \& Werb 1995, Hardy \& Handyside 1996, Hao et al. 2004). The reduction in TE cells could account for the shortage in extra-embryonic tissue and almost no trophoblast found in parthenotes arrested development (Kaufman et al. 1977).

The relative frequency of apoptosis (i.e. apoptotic ICM/TE cells) was higher in parthenotes than in IVF embryos. However, we did not observe the changes in apoptosis and necrosis indexes between parthenotes and IVF embryos, By contrast, other studies found higher apoptotic indexes $(\mathrm{AI})$ in parthenotes than in IVF embryos (Neuber et al. 2002, Hao et al. 2004, Wang et al. 2008). Frequency of diploid blastocysts was reported to be lower in parthenotes than in IVF embryos (Wang et al. 2008). Interestingly, haploidy increases the incidence of apoptosis in preimplantation embryos, while parthenogenetic activation and parthenogenesis themselves would not lead to apoptosis (Liu et al. 2002a, 2002 b, Jeong et al. 2005). Haploidy is also responsible for diminished blastocyst rates over normal embryos and diploid parthenotes (Henery \& Kaufman 1992, Jeong et al. 2005). Therefore, the enhanced diploidy we found in parthenotes is consistent with their Al (that was not increased) and improved development rates.

Parthenotes exhibited a pro-apoptotic gene expression profile as defined by their increased BAX/BCL2 ratio. This condition was not consistent with an enhanced apoptotic phenotype in parthenotes, but it could relate to pattern differences because an increased relative frequency of apoptosis was observed in the ICM over the TE. BAX and BCL2 are pro- and anti-apoptotic genes respectively, and the tendency of a cell to undergo apoptosis is continuously counterbalanced by pro- and anti-apoptotic gene expression (Duan et al. 2005). Interestingly, the mRNA for $p 66^{\text {shc }}$ was more abundant in parthenotes, contrary to $p 53$, which increased in IVF embryos. In IVF bovine embryos, the stress related protein $p 66^{\text {shc }}$ is up-regulated in the early arrest, while p53 does not seem to be involved in the same function (Favetta et al. 2004, 2007a, 2007b). Apoptosis is involved in the bovine early developmental arrest in vivo (Yang \& Rajamahendran 2002), although developmental arrest independent of apoptosis has been also described to occur in the uterus (Ikeda et al. 2006). To the best of our knowledge, there are no reports on $p 66^{\text {shc }}$ gene expression in parthenotes. However, although p $66^{\text {shc }}$ and $p 53$ might have common regulatory mechanisms under particular circumstances (Rodríguez et al. 2007), parthenotes and embryos could differ in their ability to channel apoptotic stimuli through $p 66^{\text {shc }}$ and p53 (Matsumoto et al. 1997, Yin et al. 2002).

The increase in $B A X / B C L 2$ ratio in parthenotes is consistent with a reduced expression of POU5F1. In the pig, parthenotes showed increased blastocyst yields and cell numbers in coincidence with decreased TUNELpositive nuclei and $B A X$ expression, while increasing BCL2L1 and POU5F1 expression (Choi et al. 2008). Knockdown of POU5F1 mRNA causes a reduction in the ICM cells in bovine IVF embryos (Nganvongpanit et al. 2006a), which could be a sign of diminished pluripotency. However, the ICM of our parthenotes showed no reduced cell counts and produces outgrowths (data not shown). This suggests that a reduction in POU5F1 gene expression could be not always limitative of the ICM viability as an outgrowth. In fact, embryos with different development potential, such as those produced by nuclear transfer, in vivo-derived and IVF embryos do not differ between their POU5F1 expression (Long et al. 2007). The role of POU5F1 in maintenance of pluripotency in bovine is controversial, as POU5F1 transcripts have been found both in the ICM and the TE (Degrelle etal. 2005). DNMT3A sets up the methyl-CG landscape of the genome early in the development. The reduced DNMT3A levels found in our study suggest a lower methylation activity in parthenotes, which agrees with a low expression of DNMT3A reported in female blastocysts (Bermejo-Alvarez et al. 2008) and XX ES cell lines as it compares with XY or XO lines (Zvetkova et al. 2005). Sagirkaya et al. (2006) found that the DNMT3A expression associates with a lower rate of blastocyst development. Accordingly, in the present work, reduced DNMT3A expression was observed in parthenotes, which in turn showed high blastocyst development rates. From our and the above results, it is likely that the reduced DNMT3A levels are associated with the female genome.

The PLAC8, an invasion specific gene, is more abundant in blastocysts resulting in calf delivery compared with those resulting in resorption (El-Sayed et al. 2006), and in endometrium of pregnant as compared with non-pregnant cows (Galaviz-Hernandez et al. 2003, Klein et al. 2006). These findings suggest a potential role for PLAC8 in placental development and fetus-maternal interface. Our work shows that parthenotes are not defective in expressed PLAC8. Interferontau $(T P-1)$ is produced by the trophoblast of ruminant 
species before placentation is initiated. The rapid upregulation of TP-1 expression at a time when the corpus luteum is wavering on the point of regression is essential if the pregnancy is to be maintained, while a less than robust production may contribute to embryonic loss (Roberts et al. 1990). Female bovine (Larson et al. 2001, Kimura et al. 2004), and deer embryos (Flint et al. 1997) express higher TP-1 than males and could be responsible for differential blastocyst loss. Female embryos and parthenotes produce more TP-1 than male embryos (Kubisch et al. 2003). The above findings are consistent with our increased TP-1 mRNA abundance in parthenotes. PGRMC1 is a membrane-bound progesterone receptor that mediates anti-apoptotic effects of progesterone in granulosa cells (Engmann et al. 2006, Peluso et al. 2006, 2008). Bovine embryos at early cleavage stages (Dode et al. 2006) and rat oocytes (Peluso et al. 2006) express PGRMC1. The role of PGRMC1 in development seems to be related to pregnancy recognition. Equine conceptuses from day 7 to day 14 show increased PGRMC1 (Rambags et al. 2008). The non-differential expression of PGRMC1 and PLAC8 between parthenotes and embryos, as well as the higher TP-1 expression in parthenotes, suggest that the activities represented by these genes would not be a limitation in the viability of parthenotes.

The enzyme of the aldose reductase gene (AKR1B1) exerts two activities, namely metabolizing progesterone that is important to implantation, and synthesizing PGF2 $\alpha$ and, subsequently, terminating pregnancy. $A K R 1 B 1$ is also known as the cause for cell apoptosis in somatic cells that accumulate sorbitol (Galvez et al. 2003, Wirtu et al. 2004). Expression of AKR1B1 has been detected in endometrium (Madore et al. 2003) and also in IVF bovine embryos (Dode et al. 2006, El-Sayed et al. 2006) and is associated with failure to establish pregnancy and resorption (El-Sayed et al. 2006). Perhaps, $A K R 1 B 1$ contributes to deciding the fate of the embryo through activation of apoptotic mechanisms. Its dependence on glucose could lead $A K R 1 B 1$ to address certain glucose-linked signs of sexual dimorphism, such as altered developmental kinetics and sex-based, stress resistance (Gutiérrez-Adán et al. 2006). We found an enhancement in the pentose phosphate pathway limiting rate $H 6 P D$, an X-linked gene, in parthenotes. Expression of $H 6 P D$ is increased in female embryos (Wrenzycki et al. 2002, Lopes et al. 2007), being involved in metabolic differences between male and female embryos (Iwata et al. 2002, Kimura et al. 2005, Lopes et al. 2007). However, parthenotes have been reported not to overexpress the X-linked genes, H6PD, and XIST (Wrenzycki et al. 2002), although in the latter study, embryos were picked up on day 7 and the exact blastocyst stage at which they were analyzed was not described (Wrenzycki et al. 2002). In somatic cells, the overexpression of H6PD induces the expression of prooxidative enzymes (Leopold et al. 2003, Park et al.
2006), which is consistent with the overexpression of thioredoxin $(T X N)$ in our parthenotes. The ubiquitous protein disulfide reductase TXN plays a role in the mouse implantation (Nonogaki et al. 1991), and responds to oxidative stress in bovine and mouse embryos (Nonogaki et al. 1991, Bing et al. 2003). The $T X N$ gene is downregulated in embryos that fail to give pregnancies and those leading to resorption (El-Sayed et al. 2006), while the addition of the compound to a pig embryo culture improves blastocyst formation, cell numbers, and apoptosis (Ozawa et al. 2006). The upregulation of $T X N$ in parthenotes could be beneficial to the short-term survival of these blastocysts.

Prostaglandin G/H synthase-2 (PTGS2) is barely detected at a constitutive level, while it is markedly inducible in specialized cell types (Smith et al. 2000). Inhibition of PTGS2 increases pregnancy rates after embryo transfer and lowers PGF2 $\alpha$ release (Scenna et al. 2005). Expression of PTGS2 is more abundant in blastocysts resulting in calf delivery compared with those resulting in resorption (El-Sayed et al. 2006). In bovine, the PTGS2 protein localizes to the TE, while the ICM does not express PTGS2 (Charpigny et al. 1997), suggesting that this gene is necessary for the elongation and subsequent implantation. Moreover, higher expression of PTGS2 throughout the implantation window indicates an important role for the PGs released by the embryo in mediating interactions with the uterus (Charpigny et al. 1997, Wang et al. 2002). As PTGS2 expression is time regulated during ruminant embryo development, differential expression could be related to asynchronous development between IVF and parthenogenetic embryos. Expression of $S L C 2 A 1$ was reduced in parthenotes, while SLC2A5 (a fructose transporter) did not change. Bovine in vivo derived embryos express SLC2A1 and SLC2A5 (Augustin et al. 2001, Balasubramanian et al. 2007). However, IVP embryos show reduced SLC2A1 mRNA abundance as compared with in vivo counterparts (Lazzari et al. 2002, Balasubramanian et al. 2007, Rho et al. 2007). The expression of SLC2A1 in IVP embryos has been found in the ICM and the TE (Wrenzycki et al. 2003). Embryonic respiration and expression of SLC2A1 and H6PD correlate, and SLC2A1 is down-regulated in female blastocysts (Lopes et al. 2007). Therefore, the down-regulation of SLC2A1 in parthenotes may reflect an absence of pro-oxidative conditions, such as described to occur in female blastocysts.

Compaction in cattle is less pronounced in the IVP embryos as related to in vivo embryos (Prather \& First 1993). The intercellular structures are altered in the IVP embryos (Boni et al. 1999), and the expression of genes responsible for compaction and cell-to-cell adhesion, such as GJA1 (CX43) and E-cadherin (CDH1), is diminished (Wrenzycki et al. 1996, 2001, Rizos et al. 2002, 2003). A low expression of GJA1 has been associated to low quality of IVP blastocysts (Lonergan et al. 2003a, 2003b, Rizos et al. 2003), low 
developmental competence as oocytes (Nemcova et al. 2006), and reduced survival to cryopreservation (Rizos et al. 2002). CDH1 intervenes in cell-to-cell adhesion as it associates to compaction (Pratt et al. 1982, Fleming et al. 1984), while its transcripts are found at comparable levels in the ICM and TE of bovine blastocysts (Shehu et al. 1996, Barcroft et al. 1998, Wrenzycki et al. 2003). $C D H 1$ plays an important role in the blastocyst formation and expansion, and knocking down CDH1 mRNA in bovine embryos reduces the blastocyst rate (Nganvongpanit et al. 2006b). In our study, levels of $\mathrm{CDH} 1$ did not differ between blastocysts and parthenotes, so the $C D H 1$ contribution to compaction and blastulation is not altered in parthenotes. However, GJA1 levels are diminished in parthenotes, although coexpressed connexins may compensate for one another (Houghton et al. 2002).

The composition and accumulation of fluid in the blastocoele is regulated by $\mathrm{Na} / \mathrm{K}$-ATPase, an essential activity for the differentiation of the TE. In the mouse, the expression of multiple isoforms of $\alpha$ and $\beta$ subunits by the blastocyst maintains cavitation, but targeted disruption in the $\mathrm{Na} / \mathrm{k}$-ATPase $\alpha 1$-subunit suppresses expansion and the embryo dies (Barcroft et al. 2004). Embryonic $\mathrm{Na} / \mathrm{K}$-ATPase activity increases when a nascent blastocoele cavity forms and decreases to baseline levels at full expansion (Houghton et al. 2003). We found lower ATP1A1 expression in fully expanded than in hatched blastocysts (Rodríguez et al. 2006). According to their development rates and ATP1A1 expression levels, our parthenotes did not seem to differ essentially from embryos during blastulation.

The results of this study show that 6 out of 18 genes analyzed (i.e. SLC2A5, CDH1, ATP1A1, BAX, PLAC8, $P G R M C 1$ ) were equally expressed between embryos and parthenotes. Four genes (i.e. DNMT3A, TP-1, H6PD, and $S L C 2 A 1$ ) varied in parthenotes such as reported to occur within female embryos. In addition, possible sexually dimorphic expression of $A K R 1 B 1$ merits further research, because of its association with metabolic traits differentially regulated between male and female embryos. Pregnancy recognition, as judged by the gene panel studied, would not differ from IVF embryos, as the only significant change observed was an increase in TP-1, typical from the female parthenogenetic genotype. Maybe genes involved in pregnancy recognition do not exert such a function in the blastocyst. A correct genomic imprinting could be unnecessary if a functional placenta is still not formed. Therefore, parthenogenetic blastocysts would serve as a source of stem cells, but not for implantation. Gene transcription indicates that the pro-apoptotic profile of parthenotes is more pronounced than that of embryos, which does not strictly correlate to an apoptotic phenotype. Parthenotes and embryos could differ in stress signaling ( $p 53$ and $p 66^{\text {shc }}$ ) that triggers growth arrest and eventually apoptosis. Gene expression did not shed light on compaction and blastocyst formation, as the lower expression in the parthenogenetic GJA1 did not correspond to morphological or functional differences between both blastocyst types. Metabolism related genes accounted for most changes in gene expression: H6PD, $S L C 2 A 1$ and, as hypothesized, $A K R 1 B 1$, showed changes consistent with embryos bearing the female genotype. A lower expression of OCT3/4 in parthenotes may indicate that the pluripotency in such blastocysts could be compromized, although this decrease is probably not to occur in a short term. Ultimately, de novo methylation was lower in parthenotes, as it occurs in female embryos. A proportion of the genes analyzed may explain important traits of the parthenogenetic phenotype, especially concerning cell death. Other genes are in coincidence with the genotype exhibited by female embryos. Genes that differ between parthenotes and IVF embryos are potential candidates to be imprinted, which opens doors to further research.

\section{Materials and Methods}

All reagents were purchased from Sigma, except otherwise indicated.

\section{In vitro maturation}

Cumulus-oocyte complexes (COCs) from slaughterhouse ovaries were aspirated from 3 to $8 \mathrm{~mm}$ visible follicles and processed throughout as described in a previous work (Rodríguez et al. 2007). Briefly, COCs were washed three times in holding medium (HM) consisting of TCM199 (Invitrogen), $25 \mathrm{mM}$ Hepes, and BSA $0.4 \mathrm{~g} / \mathrm{l}$, supplemented with $2 \mathrm{IU} / \mathrm{ml}$ heparin. For in vitro maturation (IVM), selected COCs were cultured for $24 \mathrm{~h}$ in bicarbonate-buffered TCM199, FSHp $(1 \mu \mathrm{g} / \mathrm{ml}), \mathrm{LH}(5 \mu \mathrm{g} / \mathrm{ml}), 17 \beta$-estradiol $(1 \mu \mathrm{g} / \mathrm{ml})$, and $10 \%$ fetal calf serum. Maturation was performed by culturing $\sim 50$ COCs in $500 \mu \mathrm{l}$ of medium at $38.7^{\circ} \mathrm{C}$ in $5 \% \mathrm{CO}_{2}$ in air with high humidity for 22-24 $\mathrm{h}$.

\section{In vitro fertilization and parthenogenetic activation}

Matured oocytes were submitted to either IVF or parthenogenetic activation (PA).

For IVF, a frozen/thawed semen straw corresponding to a single bull was layered down $1 \mathrm{ml}$ pre-equilibrated SpermTALP. After $1 \mathrm{~h}$ of incubation, $\sim 700 \mu \mathrm{l}$ of the upper layer of supernatant containing the motile sperm was removed. The sperm were centrifuged, washed, and cell sperm concentration was determined. The COCs were washed twice in HM and placed in four-well cultured dishes containing pre-equilibrated fertilization medium (Fert-TALP) with heparin $(10 \mu \mathrm{g} / \mathrm{ml}$, Calbiochem, La Jolla, CA, USA). Spermatozoa were then added at a concentration of $2 \times 106$ cells $/ \mathrm{ml}$ in $500 \mu \mathrm{l}$ medium per well containing 100 COCs for maximum. IVF was accomplished by incubating oocytes and sperm cells together for $18-20$ h at $38.7^{\circ} \mathrm{C}$ in $5 \% \mathrm{CO}_{2}$ with high humidity. Cumulus cells were detached from fertilized oocytes after IVF using a vortex. 
For PA, the cumulus cells were removed by incubation in $0.1 \%$ hyaluronidase for $2 \mathrm{~min}$ and by vortexing in M199-BSA for another $2 \mathrm{~min}$. Matured oocytes were activated with $5 \mathrm{mM}$ ionomycin for $4 \mathrm{~min}$ followed by $2 \mathrm{mM}$ 6-DMAP for $4 \mathrm{~h}$.

Both presumptive zygotes and parthenotes were washed three times in culture medium which consisted of synthetic oviduct fluid containing amino acids, citrate, and myo-inositol (mSOF), as described by Holm et al. (1999), modified with $6 \mathrm{~g} / \mathrm{l}$ BSA and no serum. In vitro culture (IVC) was made in four-well dishes with $400 \mu \mathrm{l}$ of medium layered under mineral oil at $38.7^{\circ} \mathrm{C}$ in $5 \% \mathrm{CO}_{2}, 5 \% \mathrm{O}_{2}$, and humidified air. Cleavage stages, morulae, and blastocyst development were recorded on days 3,6 , and 8 respectively (day $0=$ onset of IVF or PA).

\section{Differential cell counts}

Embryonic cells were counted in the ICM and the TE of expanded blastocysts. Embryos were fixed and stained as reported by Thouas et al. (2001). Blastocysts were incubated in $500 \mu \mathrm{l}$ BSA-free TCM199 Hepes (Invitrogen) with 1\% Triton $\mathrm{X}-100$, and $100 \mu \mathrm{g} / \mathrm{ml}$ propidium iodide for $30 \mathrm{~s}$. Samples were then fixed in $500 \mu \mathrm{l}$ ethanol with $25 \mu \mathrm{g} / \mathrm{ml}$ bisbenzimide (Hoechst 33342) and stored overnight at $4{ }^{\circ} \mathrm{C}$. These fixed and stained blastocysts were transferred directly to a glycerol droplet on a glass microscope slide. Cell counts were made using digital images obtained with an inverted microscope equipped with a u.v. excitation filter at 330-385 nm and a barrier filter at $420 \mathrm{~nm}$. TE cells were identified by their red fluorescence; ICM cells appeared blue.

\section{Apoptosis and necrosis}

Expanded blastocysts were fixed in 4\% (w/v) PBS-buffered paraformaldehyde and permeabilized with PBS containing $0.5 \%(\mathrm{v} / \mathrm{v})$ Triton-X 100 and stored overnight in PBS containing $10 \mu \mathrm{g} / \mathrm{ml}$ BSA. After washing with PBS containing $0.1 \mu \mathrm{g} / \mathrm{ml}$ PVA, the blastocysts were incubated for $1 \mathrm{~h}$ at $37^{\circ} \mathrm{C}$ in $30 \mu \mathrm{l}$ droplets of TUNEL (TdT -mediated dUTP nick-end labeling) reaction mixture (in situ Cell Death Detection Kit, Roche) under paraffin oil in darkness. Negative controls contained no TdT. Positive control was obtained by treating samples with $100 \mathrm{U} / \mathrm{ml}$ DNase I for $1 \mathrm{~h}$ at $37^{\circ} \mathrm{C}$. After the TUNEL reaction, the nuclei were stained with $10 \mu \mathrm{g} / \mathrm{ml}$ bisbenzimide diluted in PBS-PVA for $10 \mathrm{~min}$. The blastocysts were washed in PBS with $0.1 \mu \mathrm{g} / \mathrm{ml}$ PVA, mounted on a glass slide with droplets of glycerol containing $2.5 \%$ (w/v) 1,4-diazabicyclo(2.2.2) octane, flattened with a cover slip and examined under an Olympus IX50 fluorescence microscope. The wide band filters for blue and uv excitation were used for the detection of TUNEL and bisbenzimide staining respectively. Discrimination between nuclei showing apoptotic or necrotic morphology was based on a previous description (Gjørret et al. 2003), as depicted in Rodríguez et al. (2006). Briefly, TUNEL positive nuclei consisting of condensed chromatin aggregated in granular masses, pycnotic appearance or multiple fragments scattered within cellular spaces were considered as apoptotic. Nuclei that showed unclear or fluffy edges and swelling or fragmentation into numerous fluffy elements plus swelling were considered necrotic.
TE and ICM cells were enumerated separately. The allocation of cells to the TE or ICM was based on their position in the embryos and the relative size of their nuclei. Cells within the ICM appear as a mass within the embryo and have smaller nuclei than those seen in the TE cells. The ratios of apoptotic and necrotic cells to total cells were termed as the $\mathrm{Al}$ and $\mathrm{NI}$ respectively. The relative frequencies of apoptotic cells within the ICM and TE (RF) were calculated as: $\mathrm{Al}$ of the ICM/AI of the TE.

\section{Cytogenetic analysis}

The embryos developed to blastocyst stage were evaluated for their ploidy by a modification of the method of Alexander et al. (2006). In brief, embryos were synchronized at metaphase by transferring to IVC medium containing $0.1 \mu \mathrm{g} / \mathrm{ml}$ demecolcine (KaryoMAX Colcemid, Gibco BRL) for $16 \mathrm{~h}$. Then the embryos were exposed to a hypotonic solution $(0.8 \%$ sodium citrate) for $3 \mathrm{~min}$ and placed in cold methanol-glacial acetic $(3: 1)$ solution for $6 \mathrm{~h}$. The fixed embryos were carefully dropped individually onto a pre-cleaned microscope slide. Few drops of cold methanol-glacial acetic $(1: 1)$ solution were dropped over each embryo to spread the preparation. After air drying, the slides were stained with $4 \%$ Giemsa solution for 10 min and ploidy was evaluated at $\times 1000$ with oil-immersion optics. Embryos were classified as being haploid (n), diploid $(2 n)$, and polyploid ( $\geq 3 n)$.

\section{Gene expression}

\section{RNA extraction}

Pools of 15 expanded, day 8 blastocysts were snap frozen in $\mathrm{LN}_{2}$ and then stored at $-80^{\circ} \mathrm{C}$. Isolation of mRNA was performed using the Dynabeads mRNA Direct KIT (DYNAL, Oslo, Norway), following the manufacturer's instructions. The samples were lysed in $180 \mu \mathrm{l}$ lysis/binding buffer (DYNAL). Hybridization was performed with $100 \mu$ l Dynabeads oligo (dT)25 for $10 \mathrm{~min}$. Poly A RNA-beads complexes were separated from the binding buffer and rinsed in buffer $A$ and B (DYNAL), using a magnetic separator. Poly A RNA was finally eluted in $180 \mu \mathrm{l} 10 \mathrm{mM}$ Tris-HCL.

\section{Reverse transcription}

Reverse transcription was achieved using the First-Strand CDNA synthesis kit for RT-PCR, (AMV, Roche) with oligo (dT)25, following the manufacturer's instructions. The tubes were then incubated at $25^{\circ} \mathrm{C}$ for $10 \mathrm{~min}$ to allow annealing. The RNA was subsequently reverse transcribed at $42{ }^{\circ} \mathrm{C}$ for $60 \mathrm{~min}$, followed by $5 \mathrm{~min}$ incubation at $99^{\circ} \mathrm{C}$ to denature the RT enzyme. The samples were then cooled at $4{ }^{\circ} \mathrm{C}$.

\section{Real-time PCR}

Quantification was performed using a real-time PCR (qRT-PCR) method. Briefly, a Rotorgene 2000 Real Time CyclerTM (Corbett Research, Sydney, Australia) and SYBR Green (Molecular Probes, Eurogene, OR, USA) as a double-stranded 
DNA-specific fluorescent dye were used to determine the mtDNA copy number. The PCR reaction mixture $(25 \mathrm{ml})$ contained: $1 \times$ PCR buffer, $3 \mathrm{mM} \mathrm{MgCl} 2,2 \cup$ Taq Express (MWGAG Biotech, Ebersberg, Germany), $100 \mathrm{mM}$ of each dNTP, and $0.2 \mathrm{mM}$ of each primer. In addition, the doublestranded DNA dye, SYBR Green I, (1:3000 of $10000 \times$ stock solution) was included in each reaction. The PCR protocol included an initial step of $94{ }^{\circ} \mathrm{C}$ (2 min), followed by 40 cycles of $\left.94{ }^{\circ} \mathrm{C}(15 \mathrm{~s}), 56-59{ }^{\circ} \mathrm{C}(30 \mathrm{~s})\right)$, and $72{ }^{\circ} \mathrm{C}(10 \mathrm{~s})$. Fluorescence data were acquired at $83^{\circ} \mathrm{C}$ after the elongation step. The melting protocol consisted of a hold temperature at $40{ }^{\circ} \mathrm{C}$ for $60 \mathrm{~s}$ and then heating from 50 to $94{ }^{\circ} \mathrm{C}$, holding at each temperature for $5 \mathrm{~s}$ while monitoring fluorescence. Product identity was confirmed by ethidium bromide-stained $2 \%$ agarose gel electrophoresis. Experiments were conducted to contrast relative levels of each transcript and histone
$\mathrm{H} 2 \mathrm{AFZ}(\mathrm{H} 2 \mathrm{~A})$ in every sample. PCR was performed adding $2 \mu \mathrm{l}$ aliquot of each sample to the PCR mix containing the specific primers to amplify each gene. Primer sequences, the sizes of the amplified fragments of all transcripts, and the GenBank accession number are shown in Table 5. The comparative CT method was used to quantify the expression levels (Gutierrez-Adan et al. 2004). Quantification was normalized to the endogenous control, $\mathrm{H} 2 \mathrm{~A}$. Fluorescence was acquired in each cycle to determine the threshold cycle or the cycle during the log-linear phase of the reaction at which fluorescence increased above background for each sample. Within this region of the amplification curve, a difference of one cycle is equivalent to doubling of the amplified PCR product. According to the comparative $C_{\mathrm{t}}$ method, the $\Delta C_{\mathrm{t}}$ value was determined by subtracting the $H 2 A C_{\mathrm{t}}$ value for each sample from each gene $C_{\mathrm{t}}$ value of

Table 5 Primer sequences, the sizes of the amplified fragments of transcripts, and the GenBank accession number.

\begin{tabular}{|c|c|c|c|c|}
\hline Gene symbol & MGI or HGNC official name & Primers sequence $\left(5^{\prime}-3^{\prime}\right)$ & Fragment size & $\begin{array}{c}\text { GenBank } \\
\text { accession numbers }\end{array}$ \\
\hline$H 2 A F Z$ & Histone $\mathrm{H} 2 \mathrm{AFZ}$ & $\begin{array}{l}\text { 5'-AGGACGACTAGCCATGGACGTGTG } \\
\text { 5'-CCACCACСАGCAАTTGTAGCСTTG }\end{array}$ & 212 & NM_016750 \\
\hline POU5F1 & POU domain class 51 (Oct3/4) & $\begin{array}{l}\text { 5'-CGAGTATCGAGAACCGAGTG } \\
\text { 5'-CAGGGTTCTCTCCCTAGCTC }\end{array}$ & 440 & NM_174580.1 \\
\hline DNMT3A & $\begin{array}{l}\text { DNA (cytosine-5)-methyltransferase } 3 \\
\text { alpha }\end{array}$ & 5'-CTGGTGCTGAAGGACTTGGGC & 318 & XM_001252215.1 \\
\hline SHC1 SHC $\left(p 66^{\text {sho }}\right)$ & $\begin{array}{l}\text { SHC (Src homology } 2 \text { domain } \\
\text { containing) transforming protein } 1\end{array}$ & $\begin{array}{l}\text { 5'-CAGAAGAAGGGGCGGTCATC } \\
\text { 5'-GTGAGGTCTGGGGAGAAGC } \\
\text { 5'-GGTTCGGACAAAGGATCACC }\end{array}$ & 334 & NM_001075305 \\
\hline TP53 & Tumor protein p53 & $\begin{array}{l}\text { 5'-GGIICGGACAAAGGAICACC } \\
\text { CTCAGTCCTCTGCCATACTA } \\
\text { GGATCCAGGATAAGGTGAGC }\end{array}$ & 364 & U74486 \\
\hline$B A X$ & BCL2-associated X protein & $\begin{array}{l}\text { 5'-CTACTTTGCCAGCAAACTGG } \\
\text { 5'-TCCCAAAGTAGGAGAGGA }\end{array}$ & 158 & NM_173894.1 \\
\hline$B C L 2 L 1$ & BCL2-like 1 & $\begin{array}{l}\text { 5'-GGAGCTGGTGGTTGACTTTC } \\
\text { 5'-CTAGGTGGTCATTCAGGTAAG }\end{array}$ & 517 & BC147863.1 \\
\hline PLAC8 & Placenta-specific 8 & $\begin{array}{l}\text { 5'-CGGTGTTCCAGAGGTTTTTCC } \\
\text { 5'-AAGATGCCAGTCTGCCAGTCA }\end{array}$ & 163 & NM_016619 \\
\hline$T P-1$ & Interferon-tau (IFN-t) & $\begin{array}{l}\text { 5'-GCCCTGGTGCTGGTCAGCTA } \\
\text { 5'-CATCTTAGTCAGCGAGAGTC }\end{array}$ & 564 & AF238612 \\
\hline PGRMC1 & $\begin{array}{l}\text { Progesterone receptor membrane } \\
\text { component } 1\end{array}$ & $\begin{array}{l}\text { 5'-TGTGTGTCACAAATCCAGAAAG } \\
\text { 5'-AATCATGCAGTTAGGTCAATCG }\end{array}$ & 265 & AF254804 \\
\hline$S L C 2 A 1$ & $\begin{array}{l}\text { Solute carrier family } 2 \text { (facilitated } \\
\text { glucose transporter), member } 1\end{array}$ & $\begin{array}{l}\text { 5'-AGCGTCATCTTCATCCCAGC } \\
\text { 5'-CCACAATGCTCAGGTAGGAC }\end{array}$ & 540 & M60448 \\
\hline $\begin{array}{l}\text { H6PD } \\
\text { SLC2A5 }\end{array}$ & $\begin{array}{l}\text { Glucose-6-phosphate dehydrogenase } \\
\text { Solute carrier family } 2 \text { (facilitated } \\
\text { glucose transporter), member } 5\end{array}$ & $\begin{array}{l}\text { 5'-TTGCGGCCGCCGTCCTCTATGTG } \\
\text { 5'-AGTCATCTCCATCATCGTCCT }\end{array}$ & $\begin{array}{l}220 \\
531\end{array}$ & $\begin{array}{l}\text { XM_583628 } \\
\text { AF308830 }\end{array}$ \\
\hline$A K R I B I$ & Aldose reductase mRNA & $\begin{array}{l}\text { 5'-GTACCCGCCACCATGTAGGCAG } \\
\text { 5'-CGTGATCCCCAAGTCAGTGA } \\
\text { 5'-AATCCCTGTGGGAGGCACA }\end{array}$ & 152 & M314631 \\
\hline PTGS2 & Prostaglandin G/H synthase-2 & $\begin{array}{l}\text { 5'-ATCTACCCGCCTCATGTTCCT } \\
\text { 5'-GGATTAGCCTGCTTGTCTGGA }\end{array}$ & 187 & AF031698 \\
\hline$T X N$ & Thioredoxin & $\begin{array}{l}\text { 5'-ATGGTGAAACAGATTGAGAGCA } \\
\text { 5'-CGTTGGAATACTTTTCAGAGAGA } \\
\text { GAA }\end{array}$ & 154 & AF104105 \\
\hline GJA1 & Gap junction protein, alpha $1,43 \mathrm{kDa}$ & $\begin{array}{l}\text { 5'- TGCCTTTCGTTGTAACACTCA } \\
5^{\prime} \text { - AGAACACATGAGCCAGGTACA }\end{array}$ & 142 & AY382593.1 \\
\hline $\mathrm{CDH} 1$ & Cadherin 1, type $1, \mathrm{CDH} 1$ & $\begin{array}{l}\text { 5'- GACACTGGAGGTATCAGCGCAC } \\
\text { 5'- TGATCTGGACCAGCGACTTAGG }\end{array}$ & 193 & AY508164.1 \\
\hline ATP1A1 & $\begin{array}{l}\text { ATPase, } \mathrm{Na}+/ \mathrm{K}+\text { transporting, alpha } 1 \\
\text { polypeptide }\end{array}$ & $\begin{array}{l}\text { 5'- ACCTGCTGGGCATCCGAGTGAC } \\
\text { 5'- GGGAAGGCACAGAACCACCAG }\end{array}$ & 333 & BC123864.1| \\
\hline
\end{tabular}


the sample. Calculation of $\Delta \Delta C_{\mathrm{t}}$ involved using the highest sample $\Delta C_{\mathrm{t}}$ value (i.e. the sample with the lowest target expression) as an arbitrary constant to subtract from all other $\Delta C_{\mathrm{t}}$ sample values. Fold changes in the relative gene expression of the target were determined using the formula $2^{-\Delta \Delta C_{\mathrm{t}}}$.

\section{Statistical analysis}

The data were analyzed in two steps. First, the factors with significant influence were identified by categorical data modeling (CATMOD) using SAS v. 8.2 software (1999; SAS Institute Inc., Cary, NC, USA). CATMOD fits linear models to frequency response functions. Treatment and replicate were found to have significant influence on the dependent variables. Secondly, those factors identified as significant were used to produce a linear model using the general linear models procedure (GLM; SAS software). This procedure performs ANOVA for the unbalanced data. GLM was used to estimate the least-square means (LSM) for each fixed effect having a significant $F$ value. Development and apoptosis/necrosis data were transformed to frequency percentages. Blastocyst cell counts were handled as absolute values. One way repeatedmeasures ANOVA (followed by multiple pair-wise comparisons using Student-Newman-Kleus method) was used for the analysis of differences in the mRNA expression assayed by quantitative RT-PCR. Gene expression was expressed as arbitrary units.

\section{Declaration of interest}

The authors declare that there is no conflict of interest that could be perceived as prejudicing the impartiality of the research reported.

\section{Funding}

The authors received grants through the projects AGL200504479 and AGL2006-04799 from the Spanish Ministry of Science and Education. A R is sponsored by FPI and FEDER. M $M$ is sponsored by FICYT.

\section{Acknowledgements}

The authors would like to thank J Rodríguez for recovery of ovaries.

\section{References}

Alexander B, Coppola G, Di Berardino D, Rho GJ, St John E, Betts DH \& King WA 2006 The effect of 6-dimethylaminopurine (6-DMAP) and cycloheximide $(\mathrm{CHX})$ on the development and chromosomal complement of sheep parthenogenetic and nuclear transfer embryos. Molecular Reproduction and Development 73 20-30.

Augustin R, Pocar P, Navarrete-Santos A, Wrenzycki C, Gandolfi F \& Niemann H 2001 Glucose transporter expression is developmentally regulated in in vitro derived bovine preimplantation embryos. Molecular Reproduction and Development 60 370-376.
Balasubramanian S, Son WJ, Kumar BM, Ock SA, Yoo JG, Im GS, Choe SY \& Rho GJ 2007 Expression pattern of oxygen and stress-responsive gene transcripts at various developmental stages of in vitro and in vivo preimplantation bovine embryos. Theriogenology 68 265-275.

Barcroft LC, Hay-Schmidt A, Caverney A, Gilfoyle E, Overstrom EW, Hyttel P \& Watson AJ 1998 Trophectoderm differentiation in the bovine embryo: characterization of a polarized epithelium. Journal of Reproduction and Fertility 114 327-339.

Barcroft LC, Moseley AE, Lingrel JB \& Watson AJ 2004 Deletion of the $\mathrm{Na} / \mathrm{K}-\mathrm{ATPase}$ alpha1-subunit gene (Atp1a1) does not prevent cavitation of the preimplantation mouse embryo. Mechanisms of Development 121 417-426.

Bermejo-Alvarez P, Rizos D, Rath D, Lonergan P \& Gutierrez-Adan A 2008 Epigenetic differences between male and female bovine blastocysts produced in vitro. Physiological Genomics 32 264-272.

Bing YZ, Hirao Y, Takenouchi N, Che LM, Nakamura H, Yodoi J \& Nagai T 2003 Effects of thioredoxin on the preimplantation development of bovine embryos. Theriogenology 59 863-873.

Boni R, Tosti E, Roviello S \& Dale B 1999 Intracellular communication in in vivo- and in vitro-produced bovine embryos. Biology of Reproduction 61 1050-1055.

Brevini TA \& Gandolfi F 2008 Parthenotes as a source of embryonic stem cells. Cell Proliferation 41 20-30.

Charpigny G, Reinaud P, Tamby JP, Creminon C \& Guillomots M 1997 Cyclooxygenase- 2 unlike cyclooxygenase- 1 is highly expressed in ovine embryos during the implantation period. Biology of Reproduction $\mathbf{5 7}$ 1032-1040.

Choi J, Park SM, Lee E, Kim JH, Jeong YI, Lee JY, Park SW, Kim HS, Hossein MS, Jeong YW et al. 2008 Anti-apoptotic effect of melatonin on preimplantation development of porcine parthenogenetic embryos. Molecular Reproduction and Development 75 1127-1135.

Cibelli JB, Cunniff K \& Vrana KE 2006 Embryonic stem cells from parthenotes. Methods in Enzymology 418 117-135.

Degrelle SA, Campion E, Cabau C, Piumi F, Reinaud P, Richard C, Renard JP \& Hue I 2005 Molecular evidence for a critical period in mural trophoblast development in bovine blastocysts. Developmental Biology $288448-460$.

Dode MA, Dufort I, Massicotte L \& Sirard MA 2006 Quantitative expression of candidate genes for developmental competence in bovine two-cell embryos. Molecular Reproduction and Development 73 288-297.

Duan XX, Ou JS, Li Y, Su JJ, Ou C, Yang C, Yue HF \& Ban KC 2005 Dynamic expression of apoptosis-related genes during development of laboratory hepatocellular carcinoma and its relation to apoptosis. World Journal of Gastroenterology 11 4740-4744.

El-Sayed A, Hoelker M, Rings F, Salilew D, Jennen D, Tholen E, Sirard MA, Schellander K \& Tesfaye D 2006 Large-scale transcriptional analysis of bovine embryo biopsies in relation to pregnancy success after transfer to recipients. Physiological Genomics 28 84-96.

Engmann L, Losel R, Wehling M \& Peluso JJ 2006 Progesterone regulation of human granulosa/luteal cell viability by an RU486-independent mechanism. Journal of Clinical Endocrinology and Metabolism 91 $4962-4968$.

Favetta LA, Robert C, Stjohn EJ, Betts DH \& King WA 2004 p66shc, but not p53, is involved in early arrest of in vitro-produced bovine embryos. Molecular Human Reproduction 10 383-392.

Favetta LA, St John EJ, King WA \& Betts DH 2007a High levels of p66shc and intracellular ROS in permanently arrested early embryos. Free Radical Biology \& Medicine 42 1201-1210.

Favetta LA, Madan P, Mastromonaco GF, St John EJ, King WA \& Betts DH $2007 b$ The oxidative stress adaptor p66Shc is required for permanent embryo arrest in vitro. BMC Developmental Biology 7132.

Fleming TP, Warren PD, Chisholm JC \& Johnson MH 1984 Trophectodermal processes regulate the expression of totipotency within the inner cell mass of the mouse expanding blastocyst. Journal of Embryology and Experimental Morphology 84 63-90.

Flint AP, Albon SD \& Jafar SI 1997 Blastocyst development and conceptus sex selection in red deer Cervus elaphus: studies of a free-living population on the Isle of Rum. General and Comparative Endocrinology $106374-383$. 
De La Fuente R \& King WA 1998 Developmental consequences of karyokinesis without cytokinesis during the first mitotic cell cycle of bovine parthenotes. Biology of Reproduction 58 952-962.

Fukui Y, Sawai K, Furudate M, Sato N, Iwazumi Y \& Ohsaki K 1992 Parthenogenetic development of bovine oocytes treated with ethanol and cytochalasin B after in vitro maturation. Molecular Reproduction and Development 33 357-362.

Fundele R, Norris ML, Barton SC, Reik W \& Surani MA 1989 Systematic elimination of parthenogenetic cells in mouse chimeras. Development $10629-35$.

Fundele RH, Norris ML, Barton SC, Fehlau M, Howlett SK, Mills WE \& Surani MA 1990 Temporal and spatial selection against parthenogenetic cells during development of fetal chimeras. Development 108 203-211.

Galaviz-Hernandez C, Stagg C, de Ridder G, Tanaka TS, Ko MS, Schlessinger D \& Nagaraja R 2003 Plac8 and Plac9, novel placentalenriched genes identified through microarray analysis. Gene 309 81-89.

Galvez AS, Ulloa JA, Chiong M, Criollo A, Eisner V, Barros LF \& Lavandero S 2003 Aldose reductase induced by hyperosmotic stress mediates cardiomyocyte apoptosis: differential effects of sorbitol and mannitol. Journal of Biological Chemistry 278 38484-38494.

Gjorret JO, Knijn HM, Dieleman SJ, Avery B, Larsson LI \& MaddoxHyttel P 2003 Chronology of apoptosis in bovine embryos produced in vivo and in vitro. Biology of Reproduction 69 1193-1200.

Gutierrez-Adan A, Behboodi E, Murray JD \& Anderson GB 1997 Early transcription of the SRY gene by bovine preimplantation embryos. Molecular Reproduction and Development 48 246-250.

Gutierrez-Adan A, Rizos D, Fair T, Moreira PN, Pintado B, de la Fuente J, Boland MP \& Lonergan P 2004 Effect of speed of development on mRNA expression pattern in early bovine embryos cultured in vivo or in vitro. Molecular Reproduction and Development 68 441-448.

Gutierrez-Adan A, Perez-Crespo M, Fernandez-Gonzalez R, Ramirez M, Moreira P, Pintado B, Lonergan P \& Rizos D 2006 Developmental consequences of sexual dimorphism during pre-implantation embryonic development. Reproduction in Domestic Animals 41 54-62.

Hao Y, Lai L, Mao J, Im GS, Bonk A \& Prather RS 2004 Apoptosis in parthenogenetic preimplantation porcine embryos. Biology of Reproduction 70 1644-1649.

Hardy K \& Handyside AH 1996 Metabolism and cell allocation during parthenogenetic preimplantation mouse development. Molecular Reproduction and Development 43 313-322.

Henery CC \& Kaufman MH 1992 Cleavage rate of haploid and diploid parthenogenetic mouse embryos during the preimplantation period. Molecular Reproduction and Development 31 258-263.

Holm P, Booth PJ, Schmidt MH, Greve T \& Callesen H 1999 High bovine blastocyst development in a static in vitro production system using SOFaa medium supplemented with sodium citrate and myo-inositol with or without serum-proteins. Theriogenology 52 683-700.

Houghton FD, Barr KJ, Walter G, Gabriel HD, Grummer R, Traub O, Leese HJ, Winterhager E \& Kidder GM 2002 Functional significance of gap junctional coupling in preimplantation development. Biology of Reproduction 66 1403-1412.

Houghton FD, Humpherson PG, Hawkhead JA, Hall CJ \& Leese HJ 2003 $\mathrm{Na}^{+}, \mathrm{K}^{+}$, ATPase activity in the human and bovine preimplantation embryo. Developmental Biology 263 360-366.

Ikeda S, Prendes JM, Alonso-Montes C, Rodríguez A, Díez C, Kitagawa M, Imai H \& Gómez E 2006 Apoptosis-independent poor morphology of bovine embryos produced by multiple ovulation. Reproduction in Domestic Animals 41 383-385.

Iwata H, Kimura K, Hashimoto S, Ohta M, Tominaga T \& Minami N 2002 Role of G6PD activity on sex ratio and developmental competence under oxidative stress. Journal of Reproduction and Development 48 447-453.

Jellerette T, Kurokawa M, Lee B, Malcuit C, Yoon SY, Smyth J, Vermassen E, De Smedt H, Parys JB \& Fissore RA 2004 Cell cycle-coupled [Ca(2+)](i) oscillations in mouse zygotes and function of the inositol 1,4,5-trisphosphate receptor-1. Developmental Biology 274 94-109.

Jeong YJ, Cui XS, Kim BK, Kim IH, Kim T, Chung YB \& Kim NH 2005 Haploidy influences Bak and Bcl-xL mRNA expression and increases incidence of apoptosis in porcine embryos. Zygote 13 17-21.

Kaufman MH, Barton SC \& Surani MA 1977 Normal postimplantation development of mouse parthenogenetic embryos to the forelimb bud stage. Nature 265 53-55.
Kim NH, Simerly C, Funahashi H, Schatten G \& Day BN 1996 Microtubule organization in porcine oocytes during fertilization and parthenogenesis. Biology of Reproduction 54 1397-1404.

Kimura K, Spate LD, Green MP \& Roberts RM 2004 Effects of oxidative stress and inhibitors of the pentose phosphate pathway on sexually dimorphic production of IFN-tau by bovine blastocysts. Molecular Reproduction and Development 68 88-95.

Kimura K, Spate LD, Green MP \& Roberts RM 2005 Effects of D-glucose concentration, D-fructose, and inhibitors of enzymes of the pentose phosphate pathway on the development and sex ratio of bovine blastocysts. Molecular Reproduction and Development 72 201-207.

Klein C, Bauersachs S, Ulbrich SE, Einspanier R, Meyer HHD, Schmidt SEM, Reichenbach HD, Vermehren M, Sinowatz F, Blum H et al. 2006 Monozygotic twin model reveals novel embryo-induced transcriptome changes of bovine endometrium in the pre-attachment period. Biology of Reproduction 74 253-264.

Kubisch HM, Rasmussen TA \& Johnson KM 2003 Interferon-tau in bovine blastocysts following parthenogenetic activation of oocytes: pattern of secretion and polymorphism in expressed mRNA sequences. Molecular Reproduction and Development 64 79-85.

Larson MA, Kimura K, Kubisch HM \& Roberts RM 2001 Sexual dimorphism among bovine embryos in their ability to make the transition to expanded blastocyst and in the expression of the signaling molecule IFN-tau. PNAS 98 9677-9682.

Lazzari G, Wrenzycki C, Herrmann D, Duchi R, Kruip T, Niemann H \& Galli C 2002 Cellular and molecular deviations in bovine in vitro produced embryos are related to the large offspring syndrome. Biology of Reproduction 67 767-775.

Leopold JA, Zhang YY, Scribner AW, Stanton RC \& Loscalzo J 2003 Glucose-6-phosphate dehydrogenase overexpression decreases endothelial cell oxidant stress and increases bioavailable nitric oxide. Arteriosclerosis, Thrombosis, and Vascular Biology 23 411-417.

Liu CT, Chen CH, Cheng SP \& Ju JC 2002a Parthenogenesis of rabbit oocytes activated by different stimuli. Animal Reproduction Science 70 267-276.

Liu L, Trimarchi JR \& Keefe DL 2002b Haploidy but not parthenogenetic activation leads to increased incidence of apoptosis in mouse embryos. Biology of Reproduction 66 204-210.

Lonergan P, Rizos D, Gutierrez-Adan A, Moreira PM, Pintado B, de la Fuente J \& Boland MP 2003a Temporal divergence in the pattern of messenger RNA expression in bovine embryos cultured from the zygote to blastocyst stage in vitro or in vivo. Biology of Reproduction 69 1424-1431.

Lonergan P, Rizos D, Kanka J, Nemcova L, Mbaye AM, Kingston M, Wade M, Duffy P \& Boland MP 2003b Temporal sensitivity of bovine embryos to culture environment after fertilization and the implications for blastocyst quality. Reproduction 126 337-346.

Long JE, Cai X \& He LQ 2007 Gene profiling of cattle blastocysts derived from nuclear transfer, in vitro fertilization and in vivo development based on cDNA library. Animal Reproduction Science $100243-256$.

Lopes AS, Wrenzycki C, Ramsing NB, Herrmann D, Niemann H, Løvendahl P, Greve T \& Callesen H 2007 Respiration rates correlate with mRNA expression of G6PD and GLUT1 genes in individual bovine in vitro-produced blastocysts. Theriogenology 68 223-236.

Madore E, Harvey N, Parent J, Chapdelaine P, Arosh JA \& Fortier MA 2003 An aldose reductase with 20-hydroxysteroid dehydrogenase activity is most likely the enzyme responsible for the production of prostaglandin F2 in the bovine endometrium. Journal of Biological Chemistry 278 11205-11212.

Matsumoto H, Takahashi A, Wang X, Ohnishi K \& Ohnishi T 1997 Transfection of p53-knockout mouse fibroblasts with wild-type p53 increases the thermosensitivity and stimulates apoptosis induced by heat stress. International Journal of Radiation Oncology, Biology, Physics 39 197-203.

Nemcova L, Machatkova M, Hanzalova K, Horakova J \& Kanka J 2006 Gene xpression in bovine embryos derived from oocytes with different developmental competence collected at the defined follicular developmental stage. Theriogenology 65 1254-1264.

Neuber E, Luetjens CM, Chan AW \& Schatten GP 2002 Analysis of DNA fragmentation of in vitro cultured bovine blastocysts using TUNEL. Theriogenology 57 2193-2202.

Newman-Smith ED \& Werb Z 1995 Stem cell defects in parthenogenetic peri-implantation embryos. Development 121 2069-2077. 
Nganvongpanit K, Müller H, Rings F, Hoelker M, Jennen D, Tholen E, Havlicek V, Besenfelder U, Schellander K \& Tesfaye D 2006a Selective degradation of maternal and embryonic transcripts in in vitro produced bovine oocytes and embryos using sequence specific double-stranded RNA. Reproduction 131 861-874.

Nganvongpanit K, Müller H, Rings F, Gilles M, Jennen D, Holier M, Tholen E, Schellander K \& Tesfaye D 2006b Targeted suppression of E-adhering gene expression in bovine preimplantation embryo by RNA interference technology using double-stranded RNA. Molecular Reproduction and Development 73 153-163.

Nonogaki T, Noda Y, Marmot K, Unmake Y \& Mori T 1991 Protection from oxidative stress by thioredoxin and super oxide disputes of mouse embryos fertilized in vitro. Human Reproduction 6 1305-1310.

Ozawa M, Nagai T, Faradic M, Kara NW, Kaneko H, Noguchi J, Inhuman K \& Kikuchi K 2006 Addition of glutathione or thioredoxin to culture medium reduces intracellular redo status of porcine IVM/IVF embryos, resulting in improved development to the blastocyst stage. Molecular Reproduction and Development 73 998-1007.

Park J, Choe SS, Choi AH, Kim KH, Yoon MJ, Susana T, Ogawa Y \& Kim JB 2006 Increase in glucose-6-phosphate dehydrogenase in adiposities stimulates oxidative stress and inflammatory signals. Diabetes $\mathbf{5 5}$ 2939-2949.

Peluso JJ, Pappalardo A, Losel R \& Wehling M 2006 Progesterone membrane receptor component 1 expression in the immature rat ovary and its role in mediating progesterone's antiapoptotic action. Endocrinology 147 3133-3140.

Peluso JJ, Romak J \& Liu X 2008 Progesterone receptor membrane component-1 (PGRMC1) is the mediator of progesterone's antiapoptotic action in spontaneously immortalized granulosa cells as revealed by PGRMC1 small interfering ribonucleic acid treatment and functional analysis of PGRMC1 mutations. Endocrinology 149 534-543.

Prather RS \& First NL 1993 Cell-to-cell coupling in early-stage bovine embryos: a preliminary report. Theriogenology 39 561-567.

Pratt HPM, Ziomek CA, Reeve WJD \& Johnson MH 1982 Compaction of the mouse embryo: an analysis of its components. Journal of Embryology and Experimental Morphology $\mathbf{7 0}$ 113-132.

Rambags BP, van Tol HT, van den Eng MM, Colenbrander B \& Stout TA 2008 Expression of progesterone and oestrogen receptors by early intrauterine equine conceptuses. Theriogenology 69 366-375.

Reik W, Santos F, Mitsuya K, Morgan H \& Dean W 2003 Epigenetic asymmetry in the mammalian zygote and early embryo: relationship to lineage commitment? Philosophical Transactions of the Royal Society of London. Series B, Biological Sciences 358 1403-1409.

Rho GJ, S B, Kim DS, Son WJ, Cho SR, Kim JG, B MK \& Choe SY 2007 Influence of in vitro oxygen concentrations on preimplantation embryo development, gene expression and production of Hanwoo calves following embryo transfer. Molecular Reproduction and Development 74 486-496.

Rizos D, Ward F, Duffy P, Boland MP \& Lonergan P 2002 Consequences of bovine oocyte maturation, fertilization or early embryo development in vitro versus in vivo: implications for blastocyst yield and blastocyst quality. Molecular Reproduction and Development 61 234-248.

Rizos D, Gutierrez-Adan A, Perez-Garnelo S, De La Fuente J, Boland MP \& Lonergan P 2003 Bovine embryo culture in the presence of serum: implication for blastocyst development, cryotolerance, and messenger RNA expression. Biology of Reproduction 68 236-243.

Roberts RM, Schalue-Francis T, Francis H \& Keisler D 1990 Maternal recognition of pregnancy and embryonic loss. Theriogenology 33 175-183.

Rodríguez A, Diez C, Ikeda S, Royo LJ, Caamaño JN, Alonso-Montes C, Goyache F, Alvarez I, Facal N \& Gomez E 2006 Retinoids during the in vitro transition from bovine morula to blastocyst. Human Reproduction $212149-2157$.

Rodríguez A, Díez C, Caamaño JN, de Frutos C, Royo LJ, Muñoz M, Ikeda S, Facal N, Alvarez-Viejo M \& Gómez E 2007 Retinoid receptorspecific agonists regulate bovine in vitro early embryonic development, differentiation and expression of genes related to cell cycle arrest and apoptosis. Theriogenology 68 1118-1127.

Sagirkaya H, Misirlioglu M, Kaya A, First NL, Parrish JJ \& Memili E 2006 Developmental and molecular correlates of bovine preimplantation embryos. Reproduction 131 895-904.
Scenna FN, Hockett ME, Towns TM, Saxton AM, Rohrbach NR, Wehrman ME \& Schrick FN 2005 Influence of a prostaglandin synthesis inhibitor administered at embryo transfer on pregnancy rates of recipient cows. Prostaglandins \& Other Lipid Mediators 78 38-45.

Shehu D, Marsicano G, Fle'chon JE \& Galli C 1996 Developmentally regulated markers of in vitro-produced preimplantation bovine embryos. Zygote 4 109-121.

Smith AG 2001 Embryo-derived stem cells: of mice and men. Annual Review of Cell and Developmental Biology 17 435-462.

Smith WL, DeWitt DL \& Garavito RM 2000 Cyclooxygenases: structural, cellular, and molecular biology. Annual Review of Biochemistry 69 145-182.

Surani MAH, Barton SC \& Norris ML 1984 Development of reconstituted mouse eggs suggest imprinting of the genome during gametogenesis. Nature 308 548-550.

Thouas GA, Korfiatis NA, French AJ, Jones GM \& Trounson AO 2001 Simplified technique for differential staining of inner cell mass and trophectoderm cells of mouse and bovine blastocysts. Reproductive Biomedicine Online 3 25-29.

Vandaele L, Mateusen B, Maes D, de Kruif A \& Van Soom A 2006 Is apoptosis in bovine in vitro produced embryos related to early developmental kinetics and in vivo bull fertility? Theriogenology 65 1691-1703.

Van De Velde A, Liu L, Bols PE, Ysebaert MT \& Yang X 1999 Cell allocation and chromosomal complement of parthenogenetic and IVF bovine embryos. Molecular Reproduction and Development 54 57-62.

Wang H, Wen Y, Mooney S, Behr B \& Polan ML 2002 Phospholipase A2 and cyclooxygenase gene expression in human preimplantation embryos. Journal of Clinical Endocrinology and Metabolism 87 2629-2634.

Wang ZG, Wang W, Yu SD \& Xu ZR 2008 Effects of different activation protocols on preimplantation development, apoptosis and ploidy of bovine parthenogenetic embryos. Animal Reproduction Science 105 292-301.

Wirtu G, Pope CE, Damiani P, Miller F, Dresser BL, Short CR, Godke RA \& Bavister BD 2004 Development of in vitro-derived bovine embryos in protein-free media: effects of amino acids, glucose, pyruvate, lactate, phosphate and osmotic pressure. Reproduction, Fertility, and Development 15 439-449.

Wrenzycki C, Hermann D, Carnwath JW \& Niemann H 1996 Expression of the gap junction gene connexin $43(\mathrm{C} \times 43)$ in preimplantation bovine embryos derived in vitro or in vivo. Journal of Reproduction and Fertility 108 17-24.

Wrenzycki C, Herrmann D, Keskintepe L, Martins A Jr, Sirisathien S, Brackett B \& Niemann H 2001 Effects of culture system and protein supplementation on mRNA expression in pre-implantation bovine embryos. Human Reproduction 16 893-901.

Wrenzycki C, Lucas-Hahn A, Herrmann D, Lemme E, Korsawe K \& Niemann H 2002 In vitro production and nuclear transfer affect dosage compensation of the X-linked gene transcripts G6PD, PGK, and Xist in preimplantation bovine embryos. Biology of Reproduction 66 127-134.

Wrenzycki C, Herrmann D \& Niemann H 2003 Timing of blastocyst expansion affects spatial messenger RNA expression patterns of genes in bovine blastocysts produced in vitro. Biology of Reproduction 68 2073-2080.

Yang MY \& Rajamahendran R 2002 Expression of $\mathrm{Bcl}-2$ and Bax proteins in relation to quality of bovine oocytes and embryos produced in vitro. Animal Reproduction Science 70 159-169.

Yang X, Presicce GA, Moraghan L, Jiang S \& Foote RH 1994 Synergistic effect of ethanol and cycloheximide on activation of freshly matured bovine oocytes. Theriogenology 41 395-403.

Yin Y, Stahl BC, DeWolf WC \& Morgentaler A 2002 P53 and Fas are sequential mechanisms of testicular germ cell apoptosis. Journal of Andrology 23 64-70.

Zvetkova I, Apedaile A, Ramsahoye B, Mermoud JE, Crompton LA, John R, Feil R \& Brockdorff N 2005 Global hypomethylation of the genome in XX embryonic stem cells. Nature Genetics 37 1274-1279.

Received 21 May 2008

First decision 15 July 2008

Revised manuscript received 7 October 2008

Accepted 21 November 2008 